УДК [94 : 315.362] (47) «196/198»

DOI: https://doi.org/10.33782/eminak2021.2(34).530

\title{
СОЦІАЛЬНИЙ ПОРТРЕТ РАДЯНСЬКОЇ СІМ’Ї
}

\author{
Оксана Гуменюк \\ Рівненський державний гуманітарний університет (Рівне, Україна) \\ e-mail: gioks@ukr.net \\ ORCID: https://orcid.org/0000-0002-6639-7325
}

Дослідження охоплює проміжок часу, обумовлений пануванням радянської влади на українських землях і (нерідко) у свідомості украӥнців. Мета статті: визначення особливостей становлення сімейної політики радянської влади та співіснування приватного та загальнодержавного у побутовому просторі радянської сі'ї часів існування СРСР.

Подано порівняльний аналіз існування радянських сімей у різні часи існування радянської системи. Проведено частково паралелі між традиційною українською родиною у дореволюційний період і сімейними нововведеннями радянського періоду. Вказано на особливе значення ролі партії у житті радянської людини, що нерідко стосувалося і сімейно-шлюбного життя.

Ключові слова: побутовий простір, радянська система, комуністична партія, шлюб, ідеологія, сім'я

Різноманітні принципи і способи вивчення сім'ї та самореалізації у ній людини були розроблені філософами. Економістами аналізувалися господарські нюанси сімейного життя, а юристів цікавили правові основи шлюбу та сім'ї. Як соціальнопсихологічна група сім'я являла собою предмет цікавості для психологів, а проблеми ії здорового способу життя були актуальними для медиків. Соціологів цікавили розвиток і функціонування сім'ї, зразки сімейної поведінки, ролі та формальні і неформальні норми.

У ході дослідження історії звичайних сімей, на перехресті генеалогії, етнографії й історії, у 1970-х роках у Німеччині виникла повсякденна історія. Звузивши мікроісторичні спостереження до рівня сім'ї, італійські дослідники зуміли зрозуміти загальне та суспільне через бачення приватних процесів. На теренах українських земель вивченню селянської сім'ї сприяла підготовка до реформи села; а от грунтовному вивченню міської сім'ї - Перша та Друга світові війни.

Стан розробки проблеми. Проблемам дослідження сімейної історії присвячено не так багато праць, які однак подають окремі аспекти життя радянського суспільства у різних його проявах. Зокрема О. Стяжкіна у своїх працях дослідила роль жінки у повсякденні радянського побуту ${ }^{1}$. Ю. Каганов прослідкував увесь спектр ідеологічного впливу на повсякденне життя радянських громадян, зосередивши свою увагу на так званому «радянському етнотипові» ${ }^{2}$ Російські дослідники більш детально дослідили роль житлових, внутрішньородинних і сусідських відносин на фоні радянської ідеології3.

\footnotetext{
1 Стяжкіна О. Жінки в історії української культури другої половини XX століття: Монографія. Донецьк: «Східний видавничий дім», 2002. 270 с.; Стяжкіна О. Людина в радянській провінції: освоєння (від)мови. Донецьк, «Ноулідж», 2013. 295 с.

2 Каганов Ю. Конструювання «радянської людини» (1953-1991): українська версія. Запоріжжя: Інтер-М, 2019. 432 c.

3 Герасимова О. Советская коммунальная квартира как социальный институт: историкосоциологический анализ. Дисс.... канд. соц. наук. Санкт-Петербург, 2000. 274 с.; Лебина Н.Б. Энци-
} 
Метою дослідження $\epsilon$ визначення особливостей становлення сімейної політики радянської влади та співіснування приватного та загальнодержавного у побутовому просторі радянських сімей часів існування радянської системи.

Більшовицька еліта одразу поставила завдання щодо формування нової сім'ї. Оскільки доволі кволим було опрацювання питання сім'ї майбутнього, то досить поширеними виявилися утопічні уявлення про відмирання сім'ї при соціалізмі. Проголошувалися установки на те, що шлюбні стосунки можуть мати будь-якої форми, аби тільки не наносили шкоди расі та не визначалися економічним гнітом. Варто зазначити, що така сімейна політика й ідеологія не стала офіційною та панівною, а утвердила необхідність трансформації сім'ї в інтересах держави 4 .

У 1930-ті роки питання шлюбу і сім'ї стали винятково прерогативою правознавства. У післявоєнні роки поняття «радянська сім'я» та «соціалістичний спосіб життя» були взаємопов'язаними.

У 1960-1980 роки під впливом проголошеної перемоги соціалізму, холодної війни, розвитку житлового будівництва та відмирання економічно-господарської функції сім'ї при комунізмі - знову відновилися утопічні уявлення про сім'ю періоду 1920-х років.

Велика кількість публікацій про історію сім'ї у період з 1920-1970 рр. дала змогу виокремити ії̈ в особливу галузь історичної науки. Спочатку вона була зосереджена на демографічних змінах сім'ї та історії домогосподарств. Та вже з другої половини 1970-х років почали підніматися питання внутрішньосімейних стосунків і зв'язків нуклеарної сім'ї з більш численною родиною.

3 другої половини 1980-х років сім'ю почали розглядати як певний процес, в якому повсякчас переплітаються демографічні, економічні, соціальні та політичні події. Довелося аналізувати переважаючі культурні уявлення та цінності, оскільки визріли дослідження вибору членами сім'ї певних поведінкових стратегій і рішень. Сімейна історія набула комплексного характеру, оскільки шлюб виступав як процес формування сім'ї, виховання дітей - як процес її внутрішньої перебудови, старіння та смерть їі членів - як особлива стадія її розвитку. Найбільше досліджень щодо шлюбно-сімейних моделей, структури сім'ї, ролі в ній жінок і дітей, сімейного права та ідеології - припадає на 1980-ті роки. I хоча більшість з тих досліджень стосувалися селянських сімей, але індустріальному періоду розвитку радянської сім'ї теж була приділена значна увага. Головну роль у розвитку міграції з села до міста відіграли саме родинні зв'язки. Ці зв'язки й полегшили адаптацію та соціалізацію прибулих, а також найефективніше діяли задля подолання родиною суспільних криз ${ }^{5}$.

Гендерні дослідження у 1990-х роках знову привернули увагу до історії сім'ї, проблем шлюбно-сімейних стосунків в історичному аспекті. Демографічні процеси і проблеми структури сім'ї почали розглядатися засобами історичної інформатики.

Слід зазначити, що дослідження сім'ї у радянській історіографії здебільшого ет-

клопедия банальностей: Советская повседневность: Контуры, символы, знаки. Санкт-Петербург: «Дмитрий Буланин», 2006. 465 с.; Пушкарёва Н. «История повседневности» и «история частной жизни»: содержание и соотношение понятий // Социальная история. Ежегодник. Москва. 2005. С. 98-100.

4 Куновська О. Quo vadis «Історія повсякдення»? // Історіографічні дослідження в Україні. 2008. Вип. 18. С. 26.

5 Ibid. C. 29. 
нографічно-описові. Але згодом історичні дані щодо сімейної поведінки змусили сумніватися у деяких висновках теорії модернізму і процесів соціальних змін через інвентаризацію існуючих поглядів щодо великих історичних процесів, темпів їх розвитку та значення індустріалізації й урбанізації6.

Як відомо, завдяки дослідженням радянської сім'ї у 1980-х роках вчені дійшли згоди, що сім'я була найактивнішим агентом влади у процесах індустріалізації. А ще 20 років перед цим така теорія піддавалася нищівній критиці.

Оскільки у сім'ї віддзеркалюються процеси всього суспільства, то для дослідження важливо розуміти, як тут вибудовуються стосунки, розподіляються ролі, яке місце жінки у ній, коли зростає її роль з огляду на катаклізми і трагедії розвитку суспільства.

Саме 1920-ті роки з огляду на це є досить показовими, оскільки на них припадає період загострення боротьби нового та старого, коли поняття «сім'я» $\epsilon$ невизначеним і призводить до нескінченних дискусій і чвар. У цей період окрім суто патріархальних селянських сімей існувала незначна кількість міських сімей, які проживали цілком за рахунок заробітної платні. Більшість міських сімей становили такі, де тільки чоловік працював у місті, а вся родина мешкала на селі, опікуючись господарством і забезпечуючи проживання.

Після подій 1917 р. нові комуністичні ідеали починають заповнювати собою той дефіцит моральності, який утворився. Оскільки молоді жінки активно були задіяні у громадській роботі або навчанні, це значно підсилило їх авторитет у сім'ї й обмежило авторитарність чоловіка. Усе це (разом із зменшенням труднощів розлучення) породило різні моральні та ціннісні настанови у житті кожного з членів сім'ї, гострі сімейні конфлікти. Порушувалася вікова стабільність і тривалість сімейного життя7.

Як відомо, певний закон покоління спрацьовує тоді, коли змінюється світ і агентами цих змін є представники саме того покоління, для якого ситуація найбільш некомфортна. У СРСР 20-ті роки ХХ ст. дали старт зародженню сімейних стосунків радянської людини і мали відчутний вплив на усю подальшу історію шлюбу та сім'ї. Активна частина молоді намагалася зайняти основні позиції у суспільстві, яке змінювалося. Головною мішенню у боротьбі за новий побут стала сім'я як найнезахищеніша ланка мікросоціуму8.

За статистичними даними, на 1923 р. 20\% юнаків і дівчат не мали одного з батьків. І це, звичайно, не могло сприяти вихованню стійких уявлень про сім'ю9.

Усі спроби створення «нової радянської сім'ї» виглядають як моделі нового суспільства на макрорівні. Адже покоління молодих людей робило спроби віднайти себе у новому постреволюційному часі та соціумі. I тому суміш традицій і новацій у побудові сімейних стратегій породила надзвичайно складний набір ціннісних орієнтирів. Окрім того, ставлення до шлюбу та сім'ї досить часто визначалося не лише класовими чи партійними уявленнями, а й прагматикою побутових умов.

\footnotetext{
6 Радаев В. Хозяйственный мир России: советское общество // Российский экономический журнал. 1996. № 4. С. 20-27.

${ }^{7}$ Стоит ли копаться в «грязном белье»... (Российские историки размышляют над проблемами «истории частной жизни») // Родина. 1996. № 12. С. 81.

8 Герасимова М. Джерела з історії радянської повсякденності // Історичні і політологічні дослідження. Донецьк: Вид-во ДонНУ. 2007. № 1/2 (31/32). С. 293.

9 Лебина Н.Б. Энциклопедия банальностей: Советская повседневность: Контуры, символы, знаки. Санкт-Петербург: «Дмитрий Буланин», 2006. С. 277.
} 
У студентському середовищі свобода стосунків підживлювалася дискусіями і намаганнями надати їм політичного забарвлення. Тому нова соціалістична сім'я сприймалася як вільне співмешкання людей зі спільними політичними поглядами. Немало було й таких, хто вважав, що спільне проживання викривлює людські стосунки та збіднює їх.

Лише на початку 1930-х років до арсеналу радянської пропаганди увійшов лозунг «Міцна сім'я - міцна держава!» і більшовицькою партією було взято курс на зміцнення інституту шлюбу та сім'ї. Звичайно, що влада намагалася обпертися на сім'ю у встановленні контролю над повсякденним життям людей.

Як відомо, поняття «сім'я» слугує ключовою категорією дослідження державної сімейної політики і є інтегральним показником розвитку суспільства, який відображає його моральний стан і формує демографічний потенціал.

За логічного підходу поняття сім'ї визначають як соціальний інститут; як форму інституалізації відповідальності, обов'язку, інших соціальних норм, поєднаних шлюбним союзом. Сім'ю як соціальний інститут характеризують стабільність, споконвічна можливість зберігати та передавати майбутнім поколінням певні суспільні норми й цінності, взаємодія з іншими соціальними інститутами та соціальними процесами.

Фактологічний підхід визначає сім’ю як малу соціальну групу, засновану на шлюбі або кровній спорідненості чи усиновленні, зі спільною відповідальністю та допомогою.

Загалом сім'я являє собою соціальну систему з притаманними їй рисами як соціального інституту, так і малої соціальної групи. Це первинна ланка суспільства, заснована на шлюбі та родинних зв'язках, яка виконує найважливіші соціальні функції. Вона слугує своєрідним посередником між особою та державою, який протистоїть соціальному протиборству та напруженості, зберігаючи при цьому традиційні цінності.

Стосовно державної сімейної політики, головним є розуміння, які саме сім'ї потребують державної допомоги і яку сімейну ідеологію поширює та підтримує держава. Тобто, має існувати система цінностей, поглядів і настанов, які аналізують та окреслюють соціальні проблеми, а затим визначають дієві способи, спрямовані на утвердження або зміну суспільних відносин і соціальних феноменів, включаючи й громадянські шлюби ${ }^{10}$. Наступне оприлюднення та схвалення суспільством такої ідеології започатковує концепцію державної сімейної політики як монолітну науково-практичну систему, підтверджену нормативно-правовими актами, програмами, концепціями тощо.

Соціальна держава, як правило, спрямовує сімейну політику на формування такого економічного, політичного і соціокультурного середовища, в якому життєдіяльність сім'ї соціально захищена.

Якщо сімейну політику окреслювати вузько, то це - різні допомоги та послуги, спрямовані на сімейну пару з дітьми або на одиноких батьків, тобто допомоги при народженні дитини, декретні відпустки та відпустки по догляду за дитиною, система установ по догляду за дитиною, непряма державна підтримка (податкові пільги тощо).

\footnotetext{
10 Тяжельникова В. Домохозяйство горожан в 1960-1980-е гг.: структура и стратегии экономического поведения // Отечественная история. 2006. № 4. С. 54.
} 
У широкому розумінні, сімейна політика - це все, що робиться урядом і впливає на сім’ю. Тут і політика зайнятості, і сімейне законодавство, і соціальні послуги, освіта, охорона здоров'я, і політика у сфері допомоги сім'ям з пенсіонерами. Через це європейська практика сімейної політики вважається сукупністю різних політик, орієнтованих на сім'ю.

Такий різноманітний процес перебуває у постійному розвитку і тому потребує безперервного формування теоретико-методологічних засад.

Сім'я як доволі древня інституція, упродовж XX ст. пережила глибокі зміни, особливо у радянський період. Вони торкалися усіх сторін ії̈ існування.

Оновлення економічної та соціальної структури радянського суспільства, тобто індустріалізація, урбанізація, секуляризація свідомості, емансипація жінок і дітей обумовило ці зміни. Окрім того, війни та соціальні катаклізми досить дієво деформували і без того непростий і не завжди послідовний процес модернізації сім'ї 3 великою кількістю протиріч.

3 одного боку, інститут сім'ї, як і суспільство, революційно оновився, подолавши кризу патріархальної сім'ї та патріархальних сімейних стосунків, які явно відчувалися на початку століття. 3 іншого ж боку, непослідовні та незавершені зміни, які відбувалися із сім'єю, призвели до нових проблем. Сім’я, як соціальна інституція, значною мірою почала втрачати деякі життєво важливі для людини та суспільства функції. Вона опинилася на порозі нової кризи через розлад з іншими суспільними інституціями.

Тут слід торкнутися основних змін, які відбулися з сім'єю в СРСР упродовж XX ст. У 1930-ті роки чисельність селянських сімей, яких була переважна більшість у дореволюційні та перші післяреволюційні роки, почала швидко зменшуватися. Але ще на початку 1940-х років їх було понад 50\%. У другій половині 1980-х років менше 20\% населення працювало у сільськогосподарській і лісовій галузях. Тому зменшилася й відповідно частка селянських сімей ${ }^{11}$. Ці зрушення за собою визначили одну з головних змін, які відбувалися з сім'єю: за межі сім'ї перемістилася виробнича діяльність її членів. Це кардинально змінило весь характер її життя.

Паралельно відбувалися два процеси. 3 одного боку - так зване «розселянювання» сімей, а з іншого - перетворення сільських сімей, які складали більшість, у міські. Вже у довоєнний період - між переписами 1926 і 1939 років - число міських сімей збільшилося більш ніж вдвоє, тоді як чисельність населення країни виросла не більше ніж на 16\%. Звичайно, не слід забувати, що велику поправку тут внесли голодомори.

У масштабах великої країни кількісна перевага міських сімей швидко наростала, хоча цей процес відбувався неоднорідно як за темпами, так і за кількісним складом ${ }^{12}$. Як відомо, у сім'ї відображаються проблеми, притаманні суспільству в цілому. Але якщо певні матеріальні негаразди усуваються разом з успішним вирішенням на державному рівні економічних проблем, то є ряд недоліків, які не вирішуються лише економічним або соціальним розвитком. У зв'язку зі змінами історичного типу сім'ї та її взаємодією із суспільством виникають сімейні проблеми, які диктують сімейну політику держави. Адже рішення, які приймаються у різноманітних сферах соціального життя, впливають на сім’ю, хоча і не спрямовані без-

\footnotetext{
11 Платонов О. Воспоминания о народном хозяйстве. Москва: Советская Россия, 1990. С. 70.

12 Пушкарёва Н. «История повседневности» и «история частной жизни»... С. 97.
} 
посередньо на неї. Тому сімейна політика держави є складовою соціальної політики. Оскільки будь-яке суспільство доволі неоднорідне, то, за можливості, потрібно враховувати певні особливості й проводити політику диференційовано стосовно існуючих соціально-демографічних ситуацій та моделей сім'ї13.

У Радянському Союзі була своя специфіка проведення сімейної політики. Особливо цікавою для нас вона є щодо України, як специфічного регіону для усіх систем державної політики. Указом Президії ВР СРСР від 15 лютого 1947 р. були заборонені шлюби громадян СРСР з іноземцями. Безпосередній вплив на майбутнє української сім'ї мало таке явище, як переселення з інших місць країни. Особливо відчутно воно торкнулося західних регіонів України.

Із середини 1946 р. до Західної України було направлено 85 тисяч партійних функціонерів з інших регіонів Радянського Союзу (усім відома радянізація).

У 1961 р. міське населення України становило 20,6 млн. осіб, а до 1986 р. зросло на 63,6\% і становило 33,7 млн. За цей період внаслідок промислового розвитку та занепаду села сільське населення зменшилося на 23\%. 3'явився термін «неперспективні села»14. У 1968 р. був прийнятий загальносоюзний правовий акт - Основи законодавства про шлюб та сім'ю СРСР. На його основі були розроблені Кодекси всіх союзних республік, якими врегульовувалися сімейні стосунки.

30 липня 1969 р. був прийнятий Кодекс про шлюб і сім’ю. Він містив у собі новації:

- у судовому порядку стало можливим встановлення батьківства (здійснювалося посилання на спільне проживання, ведення спільного господарства або спільне виховання дітей);

- суд мав право зменшувати розмір аліментів за наявності обумовлених Законом обставин;

- вводилися норми щодо особистої власності кожного з подружжя;

- надавалося право дружині на отримання аліментів у період вагітності й упродовж півтора року після народження дитини;

- було встановлено 2 способи розірвання шлюбу: судовий та адміністративний (через РАГС).

Якісні зміни у житті сім'ї були невіддільними від кількісних. У цілому сім'я не втрачала своєї ролі як однієї з головних форм людської спільноти. Частка людей, які проживали сім'ями, залишилася досить стійкою, близькою до 90\% (у 1939 р. вона складала 89,4\%, у 1959 р. - 89,8\%, 1970 - 90,1\%, 1979 - 89,8\%, 1989 - 89,5\%)15.

У той же час середній розмір сім'ї після 1939 р. помітно зменшився, адже у 1939 р. він складав 4,1 особи на сім’ю, у 1959 р. - 3,7, 1970 - 3,7, 1979 і 1989 pp. - 3,5 особи. Це пояснюється значним зменшенням частки великих сімей - 3 п'ятьма та більше членами. У 1939 р. таких сімей було більше 35\%; у 1959 р. їх частка скоротилася до 26\%, у 1989 р. вона склала лише 18\%. За середньостатистичними загальносоюзними показниками проглядаються великі регіональні відмінності. У 1989 р. середній розмір сім'ї у Латвії та Естонії складав 3,1 особи, а у Російській Федерації, Україні, Білорусі та Литві - 3,2. У республіках Середньої Азії ці показники

\footnotetext{
13 Вайль П. 60-е: Мир советского человека. Москва: Новое литературное обозрение, 1998. С. 32. 14 Шубкин В. Социологические опыты (Методологические вопросы социальных исследований. Москва, 1970. С. 127.

15 Всесоюзная перепись населения 1989 г.: Число семей и группирова их по размеру по союзным республикам // Весник статистики. 1990. № 6. С. 78.
} 
складали: в Узбекистані - 5,5 особи, Туркменістані - 5,6, Таджикистані - 6,1. Серед сільського населення цих республік середній розмір сім'ї перевищував 6 осіб. Тут частка великих сімей з 5 і більше осіб була значною (більше 70\% у 1989 р.). На даний момент найбільш поширені три різновиди сім'ї: А - подружня пара з дітьми або без дітей (нуклеарна сім'я); Б - один із батьків з дітьми (неповна нуклеарна сім'я); В - подружня пара з дітьми або без дітей з одним із батьків подружжя й іншими родичами (складна сім'я). На частку таких сімей у 1979 р. припадало більше 91\% всіх сімей ${ }^{16}$.

Ці види сімей були найбільш поширені й у минулому, хоча їх переважання було не на стільки значним. Вочевидь, зростання частки трьох основних видів сімей історична тенденція, пов'язана з описаними раніше змінами. Водночас підвищується частка нуклеарних сімей і зменшується частка складних сімей.

Формуються та зникають сім'ї внаслідок укладання та розпаду шлюбів, народження дітей, поділу існуючих сімей і смерті їх членів. Що ж змінювалося упродовж цих процесів?

Зараз, як і колись, більшість чоловіків і жінок кожного покоління одружується. За даними перепису 1989 р., у віці 45-49 років було лише 3,2\% чоловіків і 3,3\% жінок, які ніколи не перебували у шлюбі17. Цей показник навіть менший від показника у дореволюційні роки, коли шлюбність була досить високою.

Принципових змін стосовно вікового цензу вступу в перший шлюб не відбувалося, якщо не зосереджуватися на змінах, пов'язаних з соціальними катаклізмами, війнами тощо.

За даними перепису населення 1989 р. середній вік вступу в перший шлюб для чоловіків складав 24,4 року, для жінок - 21,7. Це мало відрізнялося від показників кінця XIX ст. Суттєві зрушення спостерігалися лише у деяких республіках Закавказзя та Середньої Азії. Колись ці республіки вирізнялися ранньою шлюбністю жінок. Після змін, які тут відбулися, для них характерна швидше пізня шлюбність. У 1989 р. частка жінок, які ніколи не перебували у шлюбі, у віці 20-24 роки, склала в Азербайджані 47\%, у Грузії - 41\%, у Туркменістані - 46\%. Тоді як у РРФСР - 34\%, в УРСР - 29\%, Латвії- 38\%18.

У кінці 1980-х років увагу дослідників привернув новий феномен - поширення нереєстрованих шлюбів. Хоча пряма статистична оцінка цього феномену утруднена, але $\epsilon$ намагання оцінити його побічно, через динаміку позашлюбних народжень.

Таким чином, ми бачимо що питання про сім’ю і шлюб перемістилося переважно в царину правознавства, аніж в історію. Крім того, в історіографії у зв'язку з декларацією «перемоги соціалізму в СРСР» означився ще один стійкий напрямок протиставлення сім'ї та шлюбу при капіталізмі та соціалізмі. У післявоєнний період ця проблема стала розроблятися у контексті взаємопов'язаних понять «радянська сім'я» та «соціалістичний спосіб життя». У результаті в науковій літературі утвердився ряд міфів: про деградацію буржуазного шлюбу на противагу розквіту соціалістичної сім'ї, уявлення шлюбу при капіталізмі як модифікації товарногрошових відносин, різке протиставлення функцій сім'ї при капіталізмі та соціалізмі і т.п.

\footnotetext{
16 Ibidem.

17 Ibid. C. 78-79.

18 Ibidem.
} 


\section{REFERENCES}

Gerasimova, 0. (2000). Sovetskaia kommunalnaia kvartira kak sotsialnyi institut: istorikosotsiologicheskii analiz [Soviet communal apartment as a social institution: historical and sociological analysis]. (Candidate's thesis). Sankt-Peterburg [in Russian].

Herasimova, M. (2007). Dzherela z istorii radianskoi povsiakdennosti [Sources from the History of Soviet Everyday Life]. Istorychni i politolohichni doslidzhennia, 1/2 (31/32), 293-298 [in Ukrainian].

Kahanov, Yu. (2019). Konstruiuvannia «radianskoi liudyny» (1953-1991): ukrainska versiia [Constructing the «Soviet man» (1953-1991): Ukrainian version]. Zaporizhzhia: Inter-M [in Ukrainian].

Kunovska, 0. (2008). Quo vadis «Istoriia povsiakdennia»? [Quo vadis «History of Everyday Life»?]. Istoriohrafichni doslidzhennia v Ukraini, 18, 21-31 [in Ukrainian].

Lebina, N. (2006). Entsyklopediia banalnostei: Sovetskaia povsednevnost: Kontury, simvoly, znaki [Encyclopedia of Banalities: Soviet Everyday Life: Contours, Symbols, Signs]. Sankt-Peterburg: «Dmitriy Bulanin» [in Russian].

Platonov, 0. (1990). Vospominaniia o narodnom khoziaistve [Memories of the national economy]. Moskva: Sovetskaia Rossiia [in Russian].

Pushkariova, N. (2004). «Istoriia povsednevnosti» i «istoriia chastnoi zhyzni»: soderzhanie i sootnoshenie poniatii [«History of everyday life» and «history of private life»: content and correlation of concepts]. Socialnaia Istoria. Ezhegodnik. Moscow, pp. 98-100 [in Russian].

Radaev, V. (1996). Khoziaistvennyi mir Rossii: sovetskoie obshchestvo [The economic world of Russia: Soviet society]. Rossiiskii Ekonomicheskii Zhurnal, 4, 20-27 [in Russian].

Pushkariova, N., Tiutiukin, S., Preobrazhenskii, A. \& Bessmertnyi, Yu. (1996). Stoit li kopatsa v «griaznom belye»... [Should I delve into the «dirty linen»...]. Rodina, 12, 80-85 [in Russian].

Stiazhkina, 0. (2013). Liudyna v radianskii provintsii: osvoennia (vid)movy [Man in the Soviet province: mastering (from) the language]. Donetsk [in Ukrainian].

Stiazhkina, 0. (2002). Zhinky v istorii ukrainskoi kultury druhoi polovyny XX stolittia [Women in the History of Ukrainian Culture in the Second Half of the Twentieth Century]. Donetsk [in Ukrainian].

Tiazhelnikova, V. (2006). Domokhoziaistvo gorozhan v 1960-1980-e gg.: struktura i strategii ekonomicheskogo povedeniia [Households of citizens in the 1960-1980s: structure and strategies of economic behavior]. Otechestvennaia istoriia, 4, 53-60 [in Russian].

Shubkin, V. (1970). Sotsiologicheskie opyty (metodologicheskie voprosy sotsialnykh issledovanii) [Sociological experiments (methodological issues of social research]. Moskva [in Russian].

Vayl, P. (1998). 60-ie: Mir sovetskogo cheloveka [1960s: The World of Soviet Man] Moskva [in Russian].

\section{Oksana Gumeniuk}

(Rivne State Humanities University, Rivne, Ukraine)

e-mail: gioks@ukr.net

ORCID: https://orcid.org/0000-0002-6639-7325

\section{Social Portrait of Soviet Family}

Everyday life history is not a new trend of modern historical research, but we have little research on the life and living space of the family. The topic of the paper covers the period of Soviet power domination in Ukrainian lands and (often) in the minds of Ukrainians.

The goal of the paper is to determine the peculiarities of the Soviet government family policy formation and the coexistence of private and public in the living space of Soviet families during the existence of the Soviet system.

A comparative analysis of the existence of Soviet families at different times of the Soviet system is given. Partial parallels are drawn between the traditional Ukrainian family in the pre-revolutionary period and family innovations in the Soviet period. The special importance of the role of the party, which often concerned the family and marriage life of a Soviet man, is pointed out.

Conclusions are made about the possibility of studying the codes and laws of the USSR, which concerned the family life of Soviet people, which in turn provide an opportunity to study in more detail the individual stories on the history of everyday life of almost all social classes in the USSR. 
The memoirs, consecutively, reveal an invisible, and sometimes striking, difference in the life of the Soviet family within and outside the so-called collective.

Statistics and collections of documents provide a picture of marriages, divorces, and complaints to local authorities, which sometimes surprise with their content.

A generalized description of the position of Ukrainians as a common element of the Soviet people in the conditions of the Soviet system's existence is given.

Scientific novelty: for the first time it is shown what role the statistical data along with memories play for a better description of the everyday life of Soviet family in the conditions of double standards of the Soviet society.

Keywords: living space, Soviet system, communist party, marriage, ideology, family 